\title{
Manifest Criminality, Criminal Intent, and the Metamorphosis of Lloyd Weinreb
}

\author{
George P. Fletcher*
}

My colleague has had a revelation. Professor Lloyd Weinreb's views about larceny have undergone a striking transformation in the last six months. As recently as May 1980, when he completed the preface to the third edition of his criminal law casebook, ${ }^{1}$ he held one set of views about The Carrier's Case ${ }^{2}$ and The King v. Pear. ${ }^{3}$ In the article published in this issue, ${ }^{4}$ he advances a different set of views about the two cases he regards as so important. He gives us no hint about how or why he underwent his change of heart. His transformation warrants our attention, for by examining his conflicting positions, we shall come to appreciate another set of discontinuities-those that, despite Professor Weinreb's views, in fact shape the history of larceny.

\section{A Guide to the Issues}

Virtually all of the cases in dispute conform to the same pattern of activity. An owner voluntarily hands over his goods to $D$, whose stated purpose is to use them for a limited time. $D$ might plan to return the goods to the owner, or he might plan to deliver them to a third party. At a subsequent time, as things turn out, $D$ uses the goods in a manner inconsistent with the owner's rights. He might sell the goods to a stranger, or he might remove the contents of the package he is supposed to deliver. In any case, he converts the goods to his own use. In this course of events, it is important to note, the only time at which we can directly establish a dishonest

\footnotetext{
* Professor of Law, University of California, Los Angeles. My thanks for advice on substance and style to Guyora Binder, Dana Fellow in Comparative Jurisprudence, U.C.L.A. School of Law, 1980-81.

1. L. Weinreb, Criminal Law: Cases, Comment, Questions xvii-xx (3d ed. 1980).

2. Y. B. Pasch. 13 Edw. 4, f. 9, pl. 5 (1473), reprinted in 64 Selden Soc'y 30 (1945) [hereinafter cited to the Selden Society reprint and translation].

3. 1 Leach 212, 168 Eng. Rep. 208 (Exch. Ch. 1779).

4. Weinreb, Manifest Criminality, Criminal Intent, and the "Metamorphosis of Larceny", 90 YALE L.J. 294 (1980).
} 
purpose is that of the conversion. The intention of defendant at the time of receiving the goods remains obscure. Without extrinsic evidence, such as a confession or an admission, we have no way of knowing the defendant's purpose at the time of receipt.

With the enactment of statutes punishing embezzlement ${ }^{5}$ and larceny by bailees, ${ }^{6} \mathrm{D}$ could readily be convicted for his dishonest appropriation of the goods while he is in possession of them. Prior to those statutory modifications of the common law, however, larceny was the only applicable crime. In deciding whether $D$ was criminally liable, therefore, the courts and commentators faced two agonizingly difficult questions. First, was $D$ 's conduct larceny? Second, if it was larceny, when did the crime occur? To the latter question, there are two possible answers, and I shall refer to the two possible moments of criminality as $T_{1}$ and $T_{2}$. $T_{1}$ is the moment when $D$ first acquires physical control of the goods. $T_{2}$ is the subsequent moment when he appropriates the goods to his own use. The following chart diagrams the events in The Carrier's Case, in The King v. Pear, and in an important hypothetical problem that I shall dub the "Clever Carrier's Case":

$\begin{array}{lll} & T_{1} & T_{2} \\ \text { The Carrier's Case } & \begin{array}{l}D \text { receives the bales } \\ \text { on the understand- } \\ \text { ing that he will } \\ \text { deliver them to a }\end{array} & \begin{array}{l}\text { bales, removes their } \\ \text { contents, and } \\ \text { absconds. }\end{array}\end{array}$

The King $v$. Pear $\quad D$ receives a mare from the stable keeper on the understanding that he will ride to Surrey and back.

Clever Carrier's $\quad D$ receives the bales Case on the understanding that he will deliver them to a third party.

$D$ rides to Smithfield and sells the horse.

\author{
$D$ takes the bales to \\ Smithfield and sells \\ them to a third \\ party.
}

5. E.g., An act to protect masters against embezzlements by their clerks or servants, 39 Geo. 3, c. 85 (1799).

6. E.g., An act to make better Provision for the Punishment of Frauds committed by Trustees, Bankers, and other Persons intrusted with Property, 20 \& 21 Vict., c. 54, $\$ 4$ (1857). On similar American legislation of the nineteenth century, see $2 \mathrm{~J}$. Bishop, Commentaries on the Criminal Law \$\$ 857-871, at 476-83 (6th ed. 1877). 
The outcomes in these cases provide the basic data for our discussion. In 1473, the King's Council concluded that the carrier's conduct was felonious. ${ }^{7}$ In 1780 , the English judges came to the conclusion that Pear's overall conduct was punishable as larceny. ${ }^{8}$ We can also ascribe an outcome to the Clever Carrier's Case, even though it appears never to have been decided, for virtually every common-law commentator prior to the nineteenth century took the position that the clever carrier should not be guilty. ${ }^{9}$

If we take these data as our starting point, we confront the additional question, when did the crime in these cases occur? At $T_{1}$ or at $\mathrm{T}_{2}$ ? In the common law, the moment of criminality has always been critical. The venerable principle of concurrence, requiring a union of act and intent at one moment in time, finds its clearest application in larceny cases. In writing the Third Institute, which shaped the common law of larceny, Sir Edward Coke grasped the full significance of this required concurrence. It is worth quoting two paragraphs in full, for these lines provide the basis for nearly two centuries of thinking about larceny:

[Felonious taking.] First it must be felonious, id est, cum animo furandi [that is, with animus furandi], as hath been said. Actus non facit reum, nisi mens sit rea [no act is criminal unless accompanied by a criminal intent]. And this intent to steal must be when it cometh to his hands or possessions; for if he

7. The question whether the carrier's taking was felony was an incidental issue in the case. The question put to the justices was whether the foreign merchant could recover the goods directly from the "sheriffs of London." 64 SELDEN Soc'y, supra note 2, at 34. All of the justices of the Exchequer Chamber except Nedeham had concluded that the taking was not felonious, id. at 32-33, and that therefore the owner should have his goods. The argument against the owner before the King's Council was that the taking was felony and that therefore the goods were forfeited as waif. The King's Council concluded, in effect, that everyone was right: the taking was felonious, but nonetheless, the rules of forfeiture should not apply to an alien who had secured a "safe conduct" from the King. A legal realist would interpret this complex of views simply as the conclusion of least resistance: the justices in effect told the "sheriffs" that, even though the taking was felonious, they could not keep the goods. There is no evidence, in my view, to support the conclusion that economic conditions explain the holding that the taking was felonious. Compare J. HaLl, Theft, Law and Society 18-33 (2d ed. 1952) with G. Fletcher, Rethinking Criminal Law 68-69 (1978) [hereinafter cited without cross-reference as RETHINKING]. Recognizing the exception to the law of waif evidently furthered the interests of foreign merchants, but that aspect of the case has nothing to do with the law of theft.

8. The case was tried at Old Bailey in 1779 , but the judges did not deliver their opinion until February 1780. The King v. Pear, 1 Leach 212, 213, 168 Eng. Rep. 208, 209 (Ex. Ch. 1779).

9. See 4 W. Blackstone, Commentaries *230; E. Coke, Third Institute 107 (London 1644); M. Dalton, The Countrey Justice 259 (London 1618); 1 M. Hale, The History of the Pleas of the Crown 504 (London 1736); 1 W. Hawkins, a Treatise of the Pleas of the Crown 134 (London 1716); W. Stanford, Les Plees del Coron 25 (London 1557). 
hath the possession of it once lawfully, though he hath animum furandi afterward, and carrieth it away, it is no Larceny: but this receiveth some distinction, as hereafter shall appear,

Secondly, It must be an actual taking: for an Indictment, Quod felonice abduxit equum [that he feloniously led away the horse], is not good, because it wanteth cepit [the technical allegation of taking]. By taking, and not bailment or delivery, for that is a receipt and not a taking: and therewith agreeth Glanvil. Furtum not est ubi initium habet detentionis per dominum $r e i$. [Someone who has possession from the owner of the thing cannot be a thief]. ${ }^{10}$

This crisp account of larceny contains three important propositions, which I shall restate as applied to the above chart.

1. Larceny must occur at either $T_{1}$ or $T_{2}$. The thief cannot acquire possession twice, and if he acquires it at $T_{1}$, he must then have the animus furandi to be convicted of larceny. This is the principle of concurrence explained by the famous maxim requiring a mens rea to render the act an actus reus. ${ }^{11}$

2. In The Carrier's Case, larceny could not have occurred at $T_{1}$, for the carrier obtained the goods by "receipt," not by "taking." Therefore, the felony must have occurred at $T_{2}$.

3 . The clever carrier could not be guilty of larceny at either $T_{1}$ or $T_{2}$, for at $T_{1}$, he obtained the goods by "receipt," not by "taking," and at $T_{2}$, "he hath the possession of it once lawfully."

These three propositions dramatize the significance of the finding of felony on the facts of the actual Carrier's Case. If the clever carrier would not be guilty, why was the behavior of the actual carrier thought to be felony? Coke provided an answer in the paragraph immediately following the two quoted above. If the carrier "goeth away with the whole pack," he wrote, "this is no felony: but if he open the pack, and take any thing out animo furandi, this is larceny." ${ }^{13}$ Thus Coke explicitly followed Chokke's opinion in The

10. E. CoKe, supra note 9 , at 107 .

11. Coke coined this established principle of criminal justice, $i d$., yet nowhere did he discuss the mens rea required to render an act a "felonious taking," except, as indicated in the quoted paragraphs, to say that the act must be animo furandi. As far as I can tell, Coke used the mens rea maxim to make only two points: to explain the requirement of concurrence, id., and to explain why someone non compos mentis could not commit larceny, id. at 108, or criminal suicide, $i d$. at 54 .

12. This is the principle of possessorial immunity. For a discussion of the principle, see RETHINKING at 81-83.

13. E. CokE, supra note 9 , at 107 . 
Carrier's Case that breaking bulk at $T_{2}$ with the required animus furandi defines the larceny. This account of larceny and of The Carrier's Case appears in the work of all the major common-law commentators before the early nineteenth century. ${ }^{14}$

Using this guide to the issues and keeping clearly in mind the reading of The Carrier's Case that prevailed from Coke to Blackstone, we can begin to examine Professor Weinreb's intellectual odyssey.

\section{Professor Weinreb's First Theory of The Carrier's Case}

In the three editions of his casebook, published in 1969, 1975, and 1980, Professor Weinreb took The Carrier's Case and The King v. Pear to be critical events in the "development" of larceny. ${ }^{15}$ In his comments on The Carrier's Case, he adopted an explanation of the case that stands flatly at odds with the statements of Coke, Dalton, Hale, Hawkins, and Blackstone. After partially reproducing the opinions of the judges, ${ }^{16}$ the text poses a number of questions designed to undermine his distinction between the actual Carrier's Case and the hypothetical Clever Carrier's Case, where there would be no felony. What difference does it make, we are asked, whether the carrier took the contents of the bales or "sold them unopened"? 17 The pedagogical point of this question becomes clear fifteen pages later, when the text discloses Professor Weinreb's explanation for the finding of felony on the facts of The Carrier's Case. The thesis is that prior to the nineteenth century, the case stood for the proposition that the felony occurred at $T_{1}$, that is, at the moment that the carrier received the bales from the foreign shipper. ${ }^{18}$ If that had been the law, then there could be no difference between the actual carrier and the clever carrier. Both would have been guilty. The significance of breaking bulk or of selling bales would have been merely evidentiary. Both acts would have permitted an inference of dishonest intent at $T_{1}$.

14. Set 4 W. Blackstone, supra note 9, at $* 230$; E. Coke, supra note 9, at 107-08; M. DALTon, supra note 9, at 258-59; I M. HALE, supra note 9, at 504-05; 1 W. Hawkins, supra note 9 , at 134 .

15. Sce L. WeinReb, supra note 1 , at 355-86. Because, from the first to the third edition, there are no changes in that section of the book, reference in the text of this article is always to the third edition.

16. The most significant omission is a speech by the Chancellor saying that the applicable law was not the common law, but "the law of nature." Compare 64 Selden Soc'y, supra note 2, at 32 with L. WeINREB, supra note 1, at 360 . The omission is significant because of the considerable confusion that the Chancellor's remark suggests. See The Queen v. Ashwell, 16 Q.B.D. 190, 208 (1885) (Stephen, J., dissenting).

17. L. WeinREB, supra note 1, at 362 (question I82).

18. See id. at 377-78. 
What is Professor Weinreb's evidence for this tenuous historical claim? First, the argument relies heavily on the opinion of the Chancellor in the King's Council, ${ }^{19}$ who reportedly said, "Felony is according to the intent, and the intent here may just as well be felony as if he had not possession." 20 Second, the argument builds on the views of John Kelyng, an obscure Restoration figure, who did in fact believe that the felony occured at $T_{1}$. Kelyng reasoned that the carrier's removing of the contents of the bale and his "disposing of them to his own Use declareth that his Intent originally was not to take the Goods upon the Agreement and Contract of the Party, but only with a Design of stealing them."21 Apparently, Kelyng did not conceive of the possibility that the carrier took the goods honestly and then changed his mind. In any event, the statements of the Chancellor and of John Kelyng are the sum total of the evidence that Professor Weinreb's text offers for the apparent assumption that the common reading of The Carrier's Case prior to the nineteenth century was that the felony occurred at the time of initial receipt.

Let us look at the evidence. First, the Chancellor's opinion does not support Kelyng's theory of the case; nor does Kelyng rely on it. Note the last six words of the Chancellor's opinion: "as if he had not possession." By implication, the intent that "may be felony" is an intent to steal by one already in possession. ${ }^{22}$ It follows that the Chancellor's argument is about the carrier's intent at the time of breaking bulk. There is no plausible way to reconcile the words "as if he had not possession" with Kelyng's belief in the relevance of the carrier's intent at the time of acquiring possession. Thus, there is no conflict between the Chancellor's view and Chokke's empha-

19. See id. at 378 (Prior to the nineteenth century, "a view like that expressed by the Chancellor in the King's Council seems to have prevailed.")

20. 64 SELDEN Soc'y, supra note 2, at 31. Admittedly, Professor Weinreb's casebook does not tell us precisely how he read the Chancellor's opinion. Yet his juxtaposition of the Chancellor's emphasis on "felony according to the intent" with Kelyng's thesis implies that he regarded the two as supporting the same proposition. See L. WeINREB, supra note 1, at 377-78. His article also supports this reading of the casebook; he claims that five justices "thought that the carrier's intent was the critical issue." Weinreb, supra note 4, at 297. Because Huse, Vavasour, and Laken do seem to locate the felony at the time of taking the bales, 64 SELDEN Soc'y, supra note 2 , at 31,33 , one can only assume that Professor Weinreb has always thought that the Chancellor held the same view.

21. J. Kelyng, A Report of Divers Cases in Pleas of the Crown 82 (London 1789). The Report was originally published in 1708. Id. at A3 (advertisement by publisher).

22. Fitzjames Stephen also adopted this reading. See The Queen v. Ashwell, 16 Q.B.D. 190, 208 (1885) (Stephen, J., dissenting) ("[The Chancellor] said that a misappropriation of goods in the possession of the offender was as felonious as if they were not in his possession.") 
sis on breaking bulk, for it is at the later moment, as Blackstone correctly perceived, that the "animus furandi is manifest." 23 It is possible, of course, that the Chancellor would have found a felony in the case of the clever carrier. Unfortunately, the lawyers of the time had little chance to find out. A few months after The Carrier's Case, it seems, the Chancellor ${ }^{24}$ was dismissed from his office on grounds of "incompetency." 25 "He had every bad quality of a judge," Lord Campbell said. ${ }^{26}$ Whether competent or not, his views have had no influence on the formation of the common law.

The second source of evidence is the great Kelyng, ${ }^{27}$ whose views come to full prominence in Professor Weinreb's casebook. Without citing any support, Kelyng did in fact conclude that the felony in The Carrier's Case occurred at $\mathrm{T}_{1}$, a conclusion that Holmes dismissed as one that "hardly can be accepted."28 If Professor Weinreb had cited and analyzed the common-law authorities, perhaps we could understand his reasons for singling out Kelyng as primary authority. But the casebook does not directly cite any prenineteenth century figures except Kelyng. Why, then, this curious attachment to a minor figure? The path to Kelyng is easy to trace. Professor Weinreb's entire account of the history of larceny rests on the discussion of The King $v$. Pear in East's Pleas of the Crown ${ }^{29}$ - the work that, in my view, began the process of reinterpreting the common law of larceny. East relied on Kelyng: ${ }^{30}$

23. $4 \mathrm{~W}$. BLACKSTONE, supra note 9 , at $* 230$.

24. The Great Seal was delivered to Lawrence Booth, then Bishop of Durham, upon the resignation of Bourchier on July 27, 1473. $1 \mathrm{~J}$. CAMPBeLL, THE Lives of THE LORD Chancellors and Keepers of the Great Seal of England 391 (2d ed. 1846). Stephen concluded that therefore Booth must have been the Chancellor at the time The Carrier's Case was discussed in the King's Council. The Queen v. Ashwell, 16 Q.B.D. 190, 208 (Stephen, J., dissenting).

25. $1 \mathrm{~J}$. CAMPBeLI, sufra note 24 , at 392. Id.

26. Id. It is fair to add that, according to Lord Campbell, Booth "did not take bribes."

27. According to Lord Campbell, Kelyng "made up, by loyal zeal and subserviency, for his want of learning and sound sense." $1 \mathrm{~J}$. Campbell, The Lives of the Chief Justices of ENGLAND 403 (1851). Kelyng's subjectivist theory of liability served him well in judging suspected traitors. He was one of the few judges ever to argue that spoken words alone would support a charge of "compassing the King's Death." See J. KeLYNG, supra note 21, at 15. While serving as Chief Justice of the King's Bench, Kelyng, according to Lord Campbell, "exceeded public expectation by the violent, fantastical, and ludicrous manner in which he comported himself." I J. CampBezl, supra, at 404 . A criminal defendant once cited the Magna Charta to him, but "the only answer given by ... [the] Lord Chief Justice of England was to repeat, with a loud voice, Cromwell's rhyme, 'MAgna Charta-Magna [F]Xxxa!!!' " Id. at 154 .

28. Commonwealth v. Rubin, 165 Mass. $453,455,43$ N.E. 200, 201 (1896).

29. 2 E. East, A Treatise of the Pleas of the Crown (London 1803).

30. Id. at 687; see L. WEINREB, supra note 1, at 373-78. 
Relying on East, Professor Weinreb apparently assumed that Kelyng had accurately stated the view that prevailed prior to the nineteenth century.

Professor Weinreb's uncritical reliance on East led him to another false historical claim. His casebook teaches that "most authorities up to the time of Pear's Case" reasoned "that the carrier's deviation from the contract to carry 'determined' the bailment so that possession was restored to the merchant." ${ }^{31}$ That is patently false. No one prior to East had argued that breaking bulk "determined" the bailment. ${ }^{32}$ East cited only Hale ${ }^{33}$ whom he misinterpreted. Concurring with his predecessors, ${ }^{34}$ Hale mentioned only one case of "determining the bailment," and that was the case of the carrier who, by delivering the goods to the appointed destination, terminates the bailment according to the original contract. ${ }^{35}$

\section{Professor Weinreb's Second Theory of The Carrier's Case}

Professor Weinreb is undoubtedly right in his current view that the significance of The Carrier's Case in the common law depends not on the language of the diverse opinions, but on the way in which the case came to be understood by the architects of the common law. Yet, in his review of the authorities, he appears more concerned about fencing with a straw man than with setting forth a positive thesis. He seems to think that I deny the necessity of animus furandi in establishing common-law larceny. ${ }^{36}$ This is a curious interpretation of my published views. ${ }^{37}$ My argument is that the doctrine of breaking bulk appealed to the common-law commentators precisely because the breaking provided such good evidence of intent.

Now that he has reviewed the common-law authorities, Professor Weinreb has some difficulty affirming his original view that the carrier's felony occurred at the time of receipt. In particular, he must explain why all the commentators insisted that breaking bulk

31. L. WEINREB, supra note 1 , at 377 .

32. For my earlier exposition of this point, see Rethinking at 103; Fletcher, The Metamorphosis of Larceny, 89 HaRv. L. Rev. 469, $511-12$ (1976). Apparently, Professor Weinreb has not found my argument convincing, for he repeats his mistake in his article. See Weinreb, supra note 4, at 299.

33. 2 E. EAST, supra note 29 , at 697.

34. See, e.g., 4 W. Blackstone, supra note 9, at $\$ 230$; E. Coke, supra note 9, at 107-08.

35. I M. HALE, supra note 9 , at 505 .

36. This misinterpretation of my views accounts for the repeated emphasis on "intent" in Professor Weinreb's review of the common-law authorities. See Weinreb, supra note 4, at 300-01.

37. See Rethinking at 7, 85-86, 115-22, 388-89; Fletcher, supra note 32, at 501-02. 
was the felonious taking. In his effort to accommodate all the conflicting data in one legal formula, Professor Weinreb takes two tacks. First, he blurs the distinction between felony in the receipt and felony in the breaking. Note the obfuscation in this attempt to argue that Kelyng and Blackstone really favored the same versions of The Carrier's Case:

Although they [Kelyng and Blackstone] looked on breaking bulk as evidence of felonious intent, that fact was significant not only in itself but also (and at least in Blackstone's case primarily) because thereby the delivery did not preclude a finding of the necessary trespass. ${ }^{38}$

Professor Weinreb's play on words is nothing short of brilliant. Of course both Kelyng and Blackstone believed that, in The Carrier's Case, "the delivery did not preclude a finding of the necessary trespass." The same phrase, however, stands for two radically different propositions. For Kelyng, the delivery did not preclude a felonious taking at the time of the delivery. ${ }^{39}$ That is, Kelyng rejected Coke's basic dichotomy ${ }^{40}$ between taking and receiving by delivery. For Blackstone, as for all his noted predecessors, ${ }^{41}$ the distinction between taking and receipt represented the foundation of the common law of larceny. ${ }^{42}$ Delivery precluded larceny at that moment of time. The doctrine of breaking bulk, however, permitted a finding of felony at the subsequent moment of the breaking; ${ }^{43}$ it is in that sense, as Professor Weinreb reasons, that "delivery did not preclude a finding of the necessary trespass."

Professor Weinreb's maneuver consists in obfuscating the critical distinction between larceny at $T_{1}$ and larceny at $T_{2}$. Yet if larceny is possible at $T_{1}$, as Kelyng maintained, then the clever carrier is as guilty as the carrier; ${ }^{44}$ if larceny is possible only by virtue of breaking bulk at $T_{2}$, then, as Blackstone wrote, the clever carrier is not guilty. ${ }^{45}$ Though Kelyng and Blackstone represented diametrically

38. Weinreb, supra note 4 , at 301 n.49.

39. Sue J. KELYNG, supra note 21 , at 82.

40. Sec pp. 321-22 supra.

41. Suc note 9 supra.

42. $4 \mathrm{~W}$. BLACKSTONE, supra note 9, at $\$ 230$ ("[N]o delivery of the goods from the awner to the offender, upon trust, can ground a larceny.")

43. Id. ("But if the carrier opens a bale or pack of goods, or pierces a vessel of wine, and takes away part thereof, . . . these are larcenies; for here the animus furandi is manifest.") (footnotes omitted).

44. J. Kelyng, supra note 21 , at 83 ("I do not see why disposing of the Whole should not be Felony also.")

45. $4 \mathrm{~W}$. Blackstone, supra note 9 , at $\% 230$ ("As if $\mathrm{A}$. lends $\mathrm{B}$. a horse, and he rides 
opposed schools of thought, Professor Weinreb tries to bring their views under one verbal umbrella.

In his second eclectic maneuver, Professor Weinreb now seeks to account for the doctrine of breaking bulk by relying on Chokke's formal argument that the shipper delivered the wrappings of the bales, but not the contents. ${ }^{46}$ The implication, according to Chokke, is that when the carrier "broke open" the bales, he entered upon a domain over which the shipper retained possession. This rationale now strikes Professor Weinreb as convincing. ${ }^{47}$ Breaking bulk would appear to be the moment of felony "on the ground that Choke $e^{[48]}$ himself stated, as an analogy to the earlier cases in which a trespassory taking was found despite a prior delivery." ${ }^{49}$ Of course, if Chokke's argument explains why the commonlaw commentators relied on the event of "breaking," then one cannot maintain, as does Professor Weinreb's casebook, ${ }^{50}$ that the felony occurred at the moment of receiving the bales.

\section{Two Readings of The Carrier's Case}

In approaching a historical puzzle like the significance of The Carrier's Case in the common-law tradition, we should recognize, first, that the reading of the case might have shifted over time, and further, that the reading adopted by particular commentators tells us as much about them as it does about the case itself. My assumption is that the writers from Stanford to Blackstone adopted a view of The Carrier's Case that made sense to them. If the finding of the carrier's felony had struck them as inexplicable, they would simply have ignored this advisory opinion of the King's Council. That every important writer from Coke to Blackstone fastened on breaking open the bales as the moment of felony implies that this rationale of the case dovetailed with their conception of criminality.

By the beginning of the nineteenth century, however, the argu-

away with him; or if I send goods by a carrier, and he carries them away; these are no larcenies.")

46. 64 SELDEN Soc'y, supra note 2, at 32 ("for here the things which were in the bale were not given to him, but the bales as chose entire were delivered ut supra to carry etc.").

47. See Weinreb, supra note 4, at 303 . In his casebook, Professor Weinreb described this ground of the decision as "shaky." L. WEINREB, supra note 1 , at 377.

48. "Choke" is the law-French spelling for the English "Chokke."

49. Weinreb, supra note 4 , at 303. This statement of Chokke's rationale is mistaken in two respects. First, there is no evidence that Chokke relied on "earlier cases"; the cases he used as analogies appear to be made up. Second, it is not true that Chokke held that there "was a taking despite a prior delivery." The whole point of Chokke's argument is that the shipper did not deliver the contents and that therefore the carrier's taking of the contents was felonious.

50. See note 20 supra. 
ment that breaking bulk constituted the act of larceny no longer made sense. Beginning with East, ${ }^{51}$ one writer after another struggled to find a new interpretation of the case. ${ }^{52}$ They shifted their focus from the breaking at $T_{2}$ to the intent at $T_{1}$ and began to see the opening of the bales as merely one of many possible events that would evidence a felonious intent at $T_{1} \cdot{ }^{53}$ They cast suspicion on the original understanding of the case by developing the fiction that breaking bulk "determined" the bailment. ${ }^{54}$ That this shift occurred is indisputable. Coke, Dalton, Hale, Hawkins, and Blackstone stand for the traditional reading.55 East and Russell, with Kelyng as a precursor, represent the new reading. ${ }^{56}$

A shift in the reading of one case would not, in itself, engage much interest. What is important is that this shift correlates with analogous developments in the understanding of other doctrines in the law of larceny. Later, I shall return to these developments, and restate my interpretation of the general transformation in the structure of larceny. ${ }^{57}$ In that context, I shall explain the relevance of the two ideal types: manifest criminality and subjective criminality. Yet we need not invoke these ideal types in order to accept the conclusion that something extraordinary happened in the history of reading The Carrier's Case.

That a major transition occurred in the history of interpreting The Carrier's Case should render less surprising the reorientation that Professor Weinreb has undergone in his thinking about the case. In his casebook, Professor Weinreb identified himself with East and the newer reading of the case. In his current article, he adopts an eclectic posture and even finds an approving word for the argument that he previously regarded as "shaky." ${ }^{8}$ As we shall see, this move toward an all-embracing, single doctrine of larceny parallels the revision in his views about The King $v$. Pear.

51. 2 E. EAST, supra note 29 , at 697.

52. Ste, t.g., J. Archbold, A Summary of the Law Relative to Pleading and Evidence in Criminal Cases *124; First Report from His Majesty's Commissioners on Criminal Law, in [1834] 26 British Parliamentary Papers 121, 127; 2 W. Russell, A Treatise on Crimes and Misdeameanors 59 (5th Am. from 3d London ed., C. Greaves ed. 1845). A number of other writers have also expressed their exasperation with the doctrine of breaking bulk. See T. Plucknett, A Concise History of the Common Law 424 (4th ed. 1948) ("devious reasoning"); 3 J. Stephen, A History of the Common Law of ENGLAND 424 (1883) ("obscure distinction resting on no definite principle").

53. See 2 W. RuSSELl, supra note 52, at 59.

54. Sik J. Archbold, supra note 52, at *124-25; First Report from His Majesty's Commissioners on Criminal LAw, supra note 52, at 127-28.

55. Set note 9 supra.

56. St' notes 51, 53 supra.

57. Skt pp. 335-36 supra.

58. See L. WeinREB, supra note 1 , at 377. 


\section{Professor Weinreb's Original Understanding of The King v. Pear}

The controversy about The King $v$. Pear, like that about The Carrier's Case, focuses on the time of felony: Did the larceny occur at $T_{1}$, when Pear mounted the horse, or at $T_{2}$, when he sold the horse? As in the case of the carrier, there is authority to support both of the conflicting answers. The original report of the case, published in 1789 , supports the finding of larceny at $T_{2} \cdot{ }^{59}$ The later report by East, published in 1803, supports the finding of criminality at $\mathrm{T}_{1}{ }^{60}{ }^{60}$ It should not surprise us that Professor Weinreb's original position on Pear replicates his original views on The Carrier's Case. His initial view was that both felonies occurred at $T_{1}$, the time of receipt.

The material on Pear in the casebook begins with a few lines from the original report, ${ }^{61}$ then quotes at length from East's report of the meeting of the judges that issued in a finding of larceny. ${ }^{132}$ East's novel thesis was that, for all cases of larceny, fraud could replace the traditional requirement of force in the taking. ${ }^{63}$ The jury found that Pear had a fraudulent intent at the time of receiving the horse. ${ }^{64}$ Therefore, according to East, the moment of felony was clear: Pear committed larceny at the moment he received the horse. ${ }^{65}$ Professor Weinreb evidently subscribed to that position, for his casebook interprets Pear to stand for the proposition that fraud takes the place of force in the required taking. ${ }^{66}$

East's proposition was radical. No one in the history of larceny had ever asserted that, as a general matter, a fraudulent intent constituted the animus furandi required for larceny. As I show in my comparative study of larceny, that proposition caused the commonlaw definition of larceny to diverge from the analogous crime of larceny in France and in Germany. ${ }^{67}$ Indeed, East's theory of lar-

59. See The King v. Pear, I Leach 212, 168 Eng. Rep. 208 (Exch. Ch. 1779) (Leach's first volume published in 1789).

60. See 2 E. EAST, supra note 29 , at 685-89.

61. L. WEINREB, supra note 1 , at 373-74.

62. Id. at 374-75.

63. 2 E. EAST, supra note 29 , at 688 .

64. 1 Leach at 213, 168 Eng. Rep. at 209; see 2 E. EAST, supra note 29, at 686.

65. 2 E. EAST, supra note 29 , at 685 ("For if, under all the circumstances of the case, it be found that a party has taken goods from the owner, though by his delivery, with an intent to steal them, such taking amounts to felony.")

66. L. WEINREB, supra note 1 , at 377 ("Pear's Case is regarded as the source of the crime of larceny by trick, in which fraud replaces force as the "trespassory' element.")

67. See Rethinking at 13-26. 
ceny must be seen as the harbinger of the near collapse in English law of the distinction between theft and fraud. ${ }^{68}$

None of these extraordinary developments follow from Leach's report of the case, which, more modestly, treats Pear's fraud simply as a ground for refusing to recognize any transfer of possession to Pear, thus making it possible to treat the subsequent conversion as a felonious taking from possession. A line of cases and scholarly commentary takes this report as authoritative. ${ }^{69}$ In view of the obvious discrepancies between the two reports, one can only be baffled by Professor Weinreb's inability to perceive the difference between them.

A cursory reading of the two reports reveals these differences:

1. Leach: "[T]he parting with the property had not changed the nature of the possession ... [;] it remained unaltered in the prosecutor at the time of the conversion ....".70

East: The report makes no reference to the stablekeeper's retaining possession.

2. Leach: The report explicitly states that the felony occurred at the time of the "conversion."71

East: Neither the word "conversion" nor any synonym appears in the report or discussion.

3. Leach: The jury was asked whether, at the time of hiring, Pear had "intended to sell the horse."72

East: The jury was asked whether, at the time of hiring the mare, Pear had "an intention of stealing her." 73

4. Leach: "The jury found that the facts above stated were true ..." (special verdict). ${ }^{74}$

East: "The jury found the prisoner guilty" (general verdict). ${ }^{75}$

68. Ste Lawrence v. Metropolitan Police Comm'r, [1971] 3 W.L.R. 225, [1971] 2 All E.R. 1253 (H.L.) (theft under 1968 statute overlaps obtaining property by deception); Elliot, Thr't Problems in the Law of Theft, 9 Melbourne U.L. Rev. 448, 449-56 (1974) (discussing overlap of two offenses in English law).

69. See, e.g., Blackburn v. Commonwealth, 28 Ky. 96, 89 S.W. 160 (1905) (no conversion of hired horse and buggy if defendant pledged it with intent to redeem it); Regina $v$. Brooks, 173 Eng. Rep. 501 (1837) (offer to sell goods, without actual conversion, insufficient for finding of felony); $3 \mathrm{~J}$. STEPHEN, supra note 52, at 160 ("the subsequent conversion [is regarded] as theft").

70. 1 Leach at 213-14, 168 Eng. Rep. at 209.

71. Id. at 213-14, 168 Eng. Rep. at 209.

72. Id. at 213,168 Eng. Rep. at 209 (emphasis added).

73. 2 E. EAST, supra note 29 , at 686 .

74. I Leach at 213, 168 Eng. Rep. at 209.

75. 2 E. EAST, supra note 29 , at 686 . 
Professor Weinreb overlooked those clear differences ${ }^{76}$ because he was committed to the view that, in The Carrier's Case, the felony occurred at $T_{1}$, the moment of acquisition. In East's version of Pear, he found confirmation of what he took to be the only rational reading of both The Carrier's Case and Pear. Yet, in adjusting his reading of history to his conception of good law, he ignored the differences between the two reports, thus effacing data that are important for understanding the complexity of Anglo-American legal history.

\section{Professor Weinreb's Revised Theory of The King v. Pear}

To support his view that there is no difference between the two reports of Pear, Professor Weinreb now advances a new interpretation of the case. His thesis now is that the larceny occurs at $T_{1}$, the time of receipt, but is not complete until $\mathrm{T}_{2}$, the time of conversion. ${ }^{77}$ The new thesis, in other words, seeks to merge the two versions of Pear. This claim is nothing if not novel. If Professor Weinreb now thinks it undesirable to locate the crime at the moment Pear mounts the horse, ${ }^{78}$ then he should shift his reading to Leach's report. Yet he continues to rely on East, even as he asserts that a conversion is an essential condition of "larceny by trick."

East unequivocally committed himself to the view that the larceny occurs at the time of receipt if the suspect then has an "intent to steal."79 Professor Weinreb recognizes that East was silent on the supposed requirement of a conversion, for he writes, "Far from eliminating that requirement [of conversion], East plainly took it for granted." ${ }^{\circ 0}$ Yet he senses that this argument might not be persuasive. He therefore seeks some language from East that might support his theory. He argues as follows: "Discussing the facts of the case, he [East] says that the obtaining the possession of the mare, and afterwards disposing of her in the manner stated' was a trespass, which, accompanied by 'felonious intent at the time of obtaining the possession,' constituted larceny at common law." 81

76. Another important difference is that Leach's report describes the receipt of the horse as "fraudulent." 1 Leach at 213, 168 Eng. Rep. at 209. According to State v. Coombs, 55 Me. 477 (1867), a tortious taking might be "fraudulent," but it need not be felonious. East and Weinreb, however, read "fraudulent" as equivalent to "felonious." $S_{e e}$ p. 330 supra.

77. Weinreb, supra note 4 , at 306 .

78. See id. at 307-08.

79. See note 65 supra.

80. Weinreb, supra note 4 , at 307 .

81. Id. (emphasis in original) (footnote omitted). 
This argument, I regret to say, falsifies the record. What East in fact wrote was this:

That the obtaining the possession of the mare, and afterwards disposing of her in the manner stated, was in the construction of law such a taking as would have made the prisoner liable to an action of trespass at the suit of the owner, if he had not intended to steal her. ${ }^{82}$

Professor Weinreb misleadingly revised this statement in two respects. First, he changed the reference from an "action of trespass" to "trespass," thus suggesting that East was talking about the "trespassory" taking required for larceny, rather than about the civil action for trespass. Second, he changed the negative "if he had not intended to steal her" to the positive "accompanied by "felonious intent at the time of obtaining," "thus suggesting that East was discussing the elements of larceny.

If there is no criminal intent at the time of the taking, then, of course, the actor must do something to make himself liable in a private action for trespass. "Disposing of the horse" fulfills this requirement. If that is true for the private action, East reasons, " $[t]$ here could be no doubt but that in this case, where the felonious intent at the time of obtaining the possession was found by the jury, that it was felony by the common law." ${ }^{83}$ East's reasoning contains absolutely no suggestion that "disposing of the horse" was essential in the theory of felony. A disposition was necessary for the private action of trespass, and that is why East mentioned it while discussing the private action. It was not necessary in the theory of felony, and that is why East did not mention it in that context.

In presenting evidence to support his thesis, Professor Weinreb misrepresents another important text as well. In Regina v. Brooks, ${ }^{84}$ the court held that, even though the defendant offered to sell the goods, there was "no actual conversion of the property, and only an offer to sell ... . [T]herefore, . . . the prisoner must be acquitted." 85 In the third English edition of Russell's Treatise on Crimes and Misdemeanors, the editor, Charles Greaves, included a long footnote criticizing the rationale of Brooks. Greaves reasoned that "although no actual conversion took place,"

82. 2 E. EAST, supra note 29 , at 688 (emphasis added).

83. Id.

84. 173 Eng. Rep. 501 (1837).

85. Id. at 502 .

86. 2 W. RuSSELL, supra note 52 , at 54 n.r. 
still have gone to the jury. "An actual conversion," he said, "is undoubtedly cogent evidence that the chattel was originally obtained for that purpose; but it is only evidence . . . ."87

Despite this clear language, Professor Weinreb holds the view that Greaves remained "[f]ar from eliminating the requirement of conversion." 88 The fact is that the theory conceived by East, and advanced by Russell and Greaves, disposed of the requirement of conversion found in Leach's version of Pear. This modern theory eventually found its way into the Larceny Act of 1916, which treats "obtaining the possession "by any trick" "as one of four special ways of "taking" the property of another. ${ }^{89}$ There is, of course, no requirement of a conversion.

Professor Weinreb's primary concern has been to avoid admitting that there are conflicting theories of either The Carrier's Case or of The King v. Pear. He is impelled, therefore, to find a single, general formula for reconciling his earlier views with the obvious evidence of contrary readings. Abandoning his initial mistake in locating the felony at the time of receipt, he has failed in his efforts to find a synthesis of felony in the receipt and felony in the breaking, or conversion. As long as he seeks consistency across all the cases and across all periods in our history, Professor Weinreb is doomed to move from one mistaken general formula to another. ${ }^{90}$

\section{Discontinuities in the History of Larceny}

An interpretive theory speaks to us only if we are troubled by problematic data. If one ignores the data, as Professor Weinreb has done, then surely the interpretation will fall on covered ears. In the history of larceny, the critical data are the discontinuities between

87. Id.

88. Weinreb, supra note 4 , at 308 n.75. Greaves gave an alternative argument at the end of his footnote, but Professor Weinreb ignores it. After setting forth his preferred view of the problem, Greaves continued: "It seems difficult also to see how the fact that Mr. Orbell did not intend to complete the contract could vary the effect of the prisoner's acts; the prisoner had done all on his part to complete the contract, and as against him it might well have been held that the conversion was complete." $2 \mathrm{~W}$. Russell, supra note 52 , at 54 n.r (emphasis added). Greaves did not argue that there was a conversion, but merely that from the perspective of the defendant's guilt, the offer to sell was as good as a conversion: an offer to sell and an actual conversion would be equally strong evidence that the defendant intended to steal at the moment of receipt.

89. Larceny Act, 1916, $6 \& 7$ Geo. 5, c. 50, § 1(2)(i)(a).

90. In his study of larceny, Professor Weinreb does make two important points. First, he correctly stresses that the doctrine of in fraudem legis was a precursor to East's reading of Pear. See Weinreb, supra note 4, at 302 n.54. Second, he points out that Blackstone recognized that there might be cases of larceny other than the core cases of clandestine takings, and that, in those cases, the prosecution might have to rely on suspicious behavior after the taking in order to prove the animus furandi. Id. at 300-01. 
the traditional view and the modern view. Among these are the following:

1. The Carrier's Case

A. Traditional view: The larceny occurred at $T_{2}$, when the carrier broke open the bales." ${ }^{31}$

B. Modern view: The larceny occurred at $T_{1}$, when the carrier received the bales. ${ }^{92}$

2. The King $v$. Pear

A. Traditional view: The larcency occurred at $T_{2}$, when Pear sold the mare. ${ }^{93}$

B. Modern view: The larceny occurred at $T_{1}$, when Pear hired the mare. ${ }^{94}$

3. Color and Claim of Right

A. Traditional view: The actor had to have an observable color of right for his taking not to be felonious. ${ }^{95}$

B. Modern view: There is no felony if the actor has a subjective claim of right, "however puerile or mistaken the claim may in fact be." 96

4. The Relevance of Delivery

A. Traditional view: If the prior possessor voluntarily delivered the goods to the suspect, the latter's receipt of the goods could not constitute a punishable taking. ${ }^{97}$

B. Modern view: Voluntary delivery does not prevent the receipt from constituting a taking. ${ }^{98}$ The leading case is The Oueen $v$. Middleton, in which the defendant received excess funds from a bank teller and was convicted for larceny in the act of receiving the funds with animus furandi. ${ }^{99}$

91. Ser pp. 322-23 supra.

92. See p. 329 supra.

93. See p. 331 supra.

94. Ste p. 330 supra.

95. Set $4 \mathrm{~W}$. Blickstone, supra note 9, at $\% 232 ; 1 \mathrm{M}$. Hale, supra note 9, at 509. Hale noted that a color of right might be only "a trick to colour a felony." Id.

96. 2 J. BISHOP, supra note $6, \S 851$, at 474 (footnote omitted); see State v. Sawyer, 95 Conn. 34, 38, 110 A. 461, 463 (1920); People v. Hillhouse, 80 Mich. 580, 586, 45 N.W. 484, 486-87 (1890); Larceny Act, 1916, $6 \& 7$ Geo. 5, c. 50, \$ 1(1) (larceny negated by "claim of right"). There is no support in the common-law texts for the principle that a subjective claim of right, however irrational, should preclude liability for larceny.

97. Ste pp. 321-22 supra.

98. See note 65 supra. The Larceny Act of 1916,6 \& 7 Geo. 5, c. $50, \S 1(2)(i)$, lists three ways-by trick, by intimidation, and by mistake of the owner-of taking feloniously with the nominal consent of the owner.

99. The Queen v. Middleton, L.R. 2 Cr. Cas. Res. 38 (1873) (larceny in feloniously receiving excess funds from bank teller); see RETHINKING at 107-10 (discussing case). 


\section{The Relevance of Trespass}

A. Traditional view: Although the common-law commentators do not always mention the requirement, the general view seems to have been that a felonious taking required a trespass in the taking. ${ }^{100}$

B. Modern view: Trespass is irrelevant. None of the cases expanding liability mentions the concept, ${ }^{101}$ and the Larceny Act of 1916 refers only to "taking." one finds judges relying on the requirement of trespass only in arguing against liability. ${ }^{103}$

\section{Liability of Finders}

A. Traditional view: A finder of goods was not guilty of larceny, for there was no taking from possession. ${ }^{104}$

B. Modern view: A finder is liable if he has reason to know how to contact the owner, but fails to do so. ${ }^{105}$

Those radical discontinuities in the history of larceny are susceptible to a mode of explanation that has solid roots in social theory. ${ }^{106}$ The traditional views in the history of larceny suggest one ideal type, pattern, or paradigm of thought; the newer views coalesce as the expression of an opposing ideal type, pattern, or paradigm. ${ }^{107}$ In the concluding sections of this article, I shall de-

100. The classic texts do not mention the requirement of trespass in defining the prohibited taking. See, e.g., 4 W. Blackstone, supra note 9, at $* 230-31$; E. Coke, supra note 9, at 107; I M. Hale, supra note 9, at 506. Yet I would not say that Professor Weinreb incorrectly describes the traditional conception of the crime in stating repeatedly that larceny requires a "trespassory taking." See, e.g., Weinreb, supra note 4, at 297, 300 . Nonetheless, it would be hard to find a judicial opinion after 1800 that affirms liability on the basis of a "tresspass" in the taking. Cf. Larceny Act, 1916, 6 \& 7 Geo. 5, c. 50, § 1 (defining larceny without referring to "trespass").

101. See the various opinions favoring liability in The Queen v. Middleton, L.R. 2 Cr. Cas. Res. 38 (1873).

102. Larceny Act, $1916,6 \& 7$ Geo. 5 , c. 50 \&

103. See notes 142-43 infra.

104. See E. CoKE, supra note 9, at 108; 1 M. HALE, supra note 9, at 506.

105. See Larceny Act, 1916,6 \& 7 Geo. 5, c. 50, § l(2)(i)(d).

106. An ideal type is a set of practices and perceptions that helps make sense of otherwise enigmatic acts. The locus classicus of the method is Max Weber's explication of the ideal types of traditional, legal-rational, and charismatic authority. See M. WEBER, ThE Theory of Soctal. and Economic Organization 328-62 (A. Henderson \& T. Parsons trans., T. Parsons ed. 1947). Individuals need not be aware of the ideal type that enables their acts to have meaning to others. Id. at 111-12. Nor need the ideal ever be fully realized in a particular society. See M. Weber, 'Objectivity' in Social Science and Social Policy, in The Methodology of the Social Sciences 50, $101-03$ (E. Shils \& H. Finch trans. \& eds. 1949). The reliance on ideal types and related methods represents a growing trend in legal scholarship. See, e.g., B. Ackerman, Private Property and the Constitution (1977): Kennedy, Form and Substance in Private Law Adjudication, 89 HARv. L. REv. 1712 (1976); Simon, The Ideology of Advocacy: Procedural Justice and Professional Ethics, 1978 Wis. L. REv. 29.

107. In my earlier effort to interpret the history of tort law, I borrowed from T. KUHN, 
scribe these ideal types and explain how they enable us to understand the older and newer conceptions of larceny.

A few preliminary remarks might avoid the ubiquitous misunderstanding one finds in Professor Weinreb's reading of my views. This brief synopsis of the theory summarizes the fuller exposition of the argument in Rethinking Criminal Law. ${ }^{108}$ First, the theory consists of an elaboration of ideal types that enables us to understand seemingly unrelated cases and doctrines in the evolution of the common law. Whether those ideal types fit the data can hardly be resolved by sending the relevant data through Lexis and counting references to "manifest criminality" and "subjective criminality." Thus, in arguing that the judges and commentators do not use those terms to explain their conclusions, Professor Weinreb misses the point. The test of the theory is whether the ideal types make sense of the radical discontinuities in the history of larceny. If they help an open-minded reader to understand what others have found obscure and mysterious, then the theory succeeds as an interpretation of the historical events. If the theory fails to illuminate the data, it fails as a theory. In neither event does the validity of the argument turn on whether others have used my language.

Second, the two ideal types, subjective and manifest criminality, represent different interpretations of the venerable maxim that a crime requires (1) an act, (2) an intent, and (3) the coincidence of the act and the intent at some moment in time. ${ }^{109}$ Nowhere in my work do I even suggest that either conception of criminality would dispense with the requirement of criminal intent. Professor Weinreb must be dueling with someone else when he argues that manifest criminality leads to a form of strict liability. My point is

\footnotetext{
The Structure of Scientific Revolutions (2d ed. 1970) to argue that Kuhn's concept of "paradigm" enables us to understand a major transformation in the system of tort liability. $S_{\ell e}$ Fletcher, Faimess and Utility in Tort Theory, 85 Harv. L. Rev. 537, 540 n.12 (1972). It now seems to me, however, that there are, at a minimum, two major differences between scientific revolutions and transformations in legal doctrine. First, a new scientific paradigm totally displaces the old; the rejected paradigm does not continually reassert itself. The "paradigm of reciprocity" and the "pattern of manifest criminality," by contrast, continue to influence doctrinal disputes. Second, scientists tend to be fully aware of the paradigms they reject and adopt. Lawyers, by contrast, function at a much lower level of selfconsciousness. For those reasons, the method of ideal types has more to contribute to legal thought than does Kuhn's theory of paradigmatic change. Those and other methodological issues are explored in my article, Two Modes of Legal Thought (forthcoming 90 Yale L.J. (1981)).

108. Rethinking at 115-234.

109. For further elaboration of the latent ambiguities in this maxim common to both patterns of liability, see $i d$. at 119-22.
} 
that the two ideal types represent different interpretations of what it means to require an act and an intent. Neither ideal type dispenses with either requirement.

\section{Subjective Criminality}

As the dominant mode of thought, the conception of subjective criminality is the more accessible of the two. Under this conception, the intent to violate a protected legal interest constitutes the core of the crime. The criminal act is important, but not as evidence of what the perpetrator intended. The act might be expressly prohibited, such as "taking" the goods of another or "entering" a home with the intent to commit a felony. In the subjective theories of attempts, of treason, and of conspiracy, any act in furtherance of the criminal intent will suffice. The purpose of the act in the field of inchoate offenses is not to reveal the content of the criminal intent, but merely to demonstrate the firmness of intent. As Justice Douglas repeatedly asserted, the purpose of the act required for treason is merely to demonstrate that the "project has moved from the realm of thought into the realm of action." 110

If we review the modern conception of larceny, we find that all the data conform comfortably to this paradigm of criminality. The carrier's receiving the goods, Pear's mounting the horse, Middleton's walking away with the excess cash, and a finder's picking up an object when he knows how to locate the owner all represent completed acts of larceny. Although the critical question is whether the actor had the intent to steal, the act provides virtually no evidence of the actor's intent. For evidence, the prosecution would have to rely on a confession, on an admission, on the incriminating effect of prior convictions, or on conduct before or after the taking.

In the field of criminal attempts, the principle of subjective criminality finds its most striking application in the legislative trend toward punishing impossible attempts. Thus, according to a growing number of revised state criminal codes, an individual's conduct should be assessed according to the "attendant circumstances ... as he believes them to be."111 If a would-be killer mistakes sugar for arsenic and puts it in an enemy's coffee, his conduct unquestion-

110. Haupt v. United States, 330 U.S. 631, 645 (1947) (Douglas, J., concurring); Cramer v. United States, 325 U.S. 1, 61 (1945) (Douglas, J., dissenting).

111. E.g., Del. Code Ann. tit. 11, \$ 531(1) (1979); Mo. Ann. Stat. \$ 564.011(2) (Vernon 1979). 
ably constitutes attempted homicide. The act serves merely to demonstrate that the killer was serious about his purpose.

In drawing the line between preparation and attempt, the Model Penal Code hedges against permitting any "substantial step" in furtherance of the criminal intent to satisfy the requirement of a criminal act. ${ }^{112}$ The Code adds the requirement that the act be "strongly corroborative of the actor's criminal purpose." 113 This restriction has two flaws. First, it is a matter not of substance, but of evidence; therefore, it is readily replaced by other forms of evidence. Second, it is flatly inconsistent with the Code's dispensing with corroboration in the field of impossible attempts. ${ }^{114}$ It is not surprising, then, that in the reception of the Model Penal Code, the states have unhesitatingly abandoned the corroboration requirement. Of roughly twenty-five states that have revised their codes in this area, seventeen now define a criminal attempt simply as a "substantial step" in furtherance of the criminal intent. ${ }^{115}$ Of these, only four require that the "substantial attempt" corroborate the actor's intent or purpose. ${ }^{116}$ The elimination of the corroboration requirement confirms the general drift toward the subjectivist theory that intent is the critical element in a criminal attempt. There is no reason, under this theory, to insist upon the act of attempting as a form of corroborating evidence.

The theory of subjective criminality should not appear novel: it is, in fact, the reigning theory. It would hardly be interesting if it did not stand in sharp contrast to a less fashionable conception of criminality that stresses the manifest quality of the criminal act.

112. Ske Model Penal Code $\$ 5.01(1)(c)$ (1962).

113. Id. \$ 5.01(2).

114. Ser id. $\$ 5.01(1)(\mathrm{a})$, (b).

115. Among these 17, one finds an important distinction between states that require that the act actually be a "substantial step" and states that extend liability to acts that are a substantial step under the circumstances as the actor believes them to be. The first group consists of 13 states. Ark. Stat. AnN. $\$ 41-701(1)(b)$ (1975); Colo. Rev. Stat. $\$$ 18-2-101(1) (1978); Ga. Code Ann. \$ 26-1001 (1978); Ill. Ann. Stat. ch. 38, \$ 8-4 (SmithHurd 1972); Ind. Code ANN. \$ 35-41-5-1(a) (Burns 1979); ME. Rev. STAt. ANn. tit. 17-A, § 152(1) (1975); MINN. STAT. ANN. \$ 609.17 (West 1964); Mont. Code ANN. $\$ 45-4-103$ (1979); N.D. Cent. Code \$ 12.1-06-01 (1976); Or. Rev. Stat. \$ 161.405 (1979); Pa. Stat. ANN. tit. 18, \$90I (Purdon 1973); Utah Code ANN. \$ 76-4-101 (1978); Wash. Rev. Code ANN. \$ 9A.28.020 (1977). In contrast, four states take a subjective view of the "substantial step" requirement, under which measures in the direction of an impossible attempt would appear to be sufficient. Conn. Gen. Stat. \$ 53a-49 (1979); Del. Code ANN. tit. 11, \$531 (1979); Hawair Rev. Stat. \$ 705-500 (1976); Ky. Rev. Stat. \$ 506.010(b) (1975).

116. ARK. Stat. ANN. \$ 41-701(1)(b) (1975); Conn. Gen. Stat. \$ 53a-49 (1979); Hawail Rev. Stat. \$ 705-500 (1976); Utah Code AnN. § 76-4-101 (1978). A few other states require that the act corroborate the "firmness" of the intent. E.g., Colo. Rev. STat. $\$$ 18-2-101(1) (1978); N.D. CENT. CODE § 12.1-06-01 (1976). 


\section{Manifest Criminality}

The critical implication of subjective criminality is that an act "quite innocent on its face"117 may qualify as a criminal act. It does not matter whether mounting the horse, taking the excess cash, or putting the sugar into the coffee incriminates the actor. We trust the police to elicit other forms of evidence to establish the required intent. Confessions are good evidence, as are admissions to friends of the suspect. Prior convictions will do, as will secretive conduct after the incident. ${ }^{118}$

The principle of manifest criminality rejects the possibility of convicting someone of larceny, burglary, treason, or attempt on the basis of an act not incriminating on its face. The requirement of a criminal act takes on a different meaning under this conception of criminal behavior: the act must permit an inference of criminal intent. This is not to say, as I have always hastened to add, that the act in any way replaces or deemphasizes the requirement of criminal intent. Although the two elements of manifest criminality are lexically ordered, this means only that the first question in analyzing liability is whether the act is of the sort that permits an inference of criminal intent. The second question is always whether, in the particular case, the evidence establishes the required intent beyond a reasonable doubt. We reach the issue of intent only if we first find a manifestly criminal act. But this ordering does not render proof of intent any less necessary for liability. ${ }^{119}$

It is easy to state the principles of manifest criminality and equally easy to find dramatic instances in the cases. I shall begin by discussing a recent case in the field of impossible attempts, then turn to the reliance on manifest criminality in treason cases, and finally bring the discussion back to the history of larceny.

In United States $v$. Oriedo, ${ }^{120}$ the defendant had engaged in conduct that would be readily classified as a punishable attempt under the laws of most states. He had sold to an undercover agent a substance that both parties treated as heroin. It turned out, however, to be procaine hydrochloride, an uncontrolled substance. The jury

117. Haupt v. United States, 330 U.S. 631,646 (1947) (Douglas, J., concurring) (act that is innocent on its face is sufficient to constitute treason under Constitution).

118. For expressions of concern about relying on this type of evidence, see United States v. Oviedo, 525 F.2d 881 (5th Cir. 1976). The case is discussed below. See pp. $340-42$ infra.

119. For further elaboration of this conception of criminality, see Rethinking at 115-18, 232-33, 388, 471-72.

120. 525 F.2d 881 (5th Cir. 1976). 
found that Oviedo had thought the substance was heroin and therefore found him guilty of attempted distribution of heroin.

The framing of the issues on appeal is particularly significant. Because of the jury's finding of intent, the court of appeals took "as fact Oviedo's belief that the substance was heroin."121 The sole question on appeal was whether, as a matter of law, the sale qualified as a criminal act. The court of appeals concluded that it did not, and reversed the conviction. The opinion reflects a strong commitment to the principles of manifest criminality. Note the following passages:

Thus, we demand that in order for a defendant to be guilty of a criminal attempt, the objective acts performed, without any reliance on the accompanying mens rea, mark the defendant's conduct as criminal in nature. The acts should be unique rather than so commonplace that they are engaged in by persons not in violation of the law ....

... We cannot conclude that the objective acts of Oviedo apart from any indirect evidence of intent mark his conduct as criminal in nature. Rather, those acts are consistent with a noncriminal enterprise ....

... [H]ere, Oviedo stated he would sell heroin and then sold procaine. Based on these objective facts, we cannot infer that he intended to do that which he said he was going to do, because he in fact did something else. ${ }^{122}$

It might be difficult to grasp how the judges could both assume that Oviedo intended to sell heroin and decide that, "because he in fact did something else," they could not infer that he intended to sell heroin. The paradox is easily resolved by recognizing the court's implicit reliance on the distinction ${ }^{123}$ between a type of act and a token of the type, namely, the particular act of the defendant. This distinction helps to clarify the two stages for analyzing liability under the principle of manifest criminality.

1. The type of act must permit an inference of criminal intent. The inference might well fall short of proof beyond a reason-

121. Id. at 883 .

122. Id. at $885-86$.

123. The distinction between type and token has its roots in the philosophy of language. Nouns and verbs are word-types; a particular use of a noun or verb is a token of that type. See Brody, Logical Terms, in 5 Encyclopedia or Philosophy 76 (1967). 
able doubt. ${ }^{124}$ Whether the act yields the required inference is a question of law, resolved by the trial judge and subject to appellate review.

2. The prosecution must prove beyond a reasonable doubt that, under the particular facts of the case, the defendant had the requisite criminal intent.

If the defendant actually sold heroin to the undercover agent, the type of act would permit an inference of intent. Yet, if there was evidence that the defendant did not know the substance was heroin, the prosecution would not be able to establish guilt beyond a reasonable doubt. In Oviedo, conversely, extrinsic evidence of secretive behavior induced the jury to find that the defendant believed the substance was heroin. ${ }^{125}$ Yet, because the type of act was ambiguous, the act was not a criminal attempt, and therefore the intent was irrelevant.

There is no denying that the principles of manifest criminality inform Oviedo and the analogous statutes and cases that insist that the attempt "unequivocally" declare the actor's purpose. ${ }^{126}$ The same principles of criminality find clear expression in the treason cases, in which the recurrent problem is whether the alleged giving of aid and comfort to the enemy meets the constitutional threshold of an "overt act." In United States $v$. Robinson, ${ }^{127}$ Judge Learned Hand ruled that the act of traveling back and forth to Holland did not meet the constitutional test, even though there was ample extrinsic evidence of the defendant's treasonous purpose. The flaw in the alleged act was that it did "not openly manifest any treason." 28 In Haupt $v$. United States, ${ }^{129}$ the Supreme Court eventually rejected this test for treasonous acts, but not without a vigorous dissent from Justice Murphy. As the lone dissenter, Justice Murphy argued that the act requirement for treason had to be "consistent only with a treasonable intention." 130 Here, as in the field of attempts, we find indisputable evidence of judges committed to the

124. The strength of the required inference is left vague. See RETHINkING at 232 ("The act must bespeak danger, but it may do so in varying degress.")

125. 525 F.2d 88I, 882 n.4 ("the procaine was secreted inside a television set").

126. E.g., Wis. STAT. ANN. $\$ 939.32$ (West 1958). Delaware and Kentucky define a "substantial step" as an act or omission "which leaves no reasonable doubt as to the defendant's intention to commit the crime." Del. Code ANN. tit. 11, 532 (1979); Ky. Rev. Stat. $\S 506.010(2)$ (1975).

127. 259 F. 685 (S.D.N.Y. 1919).

128. Id. at 690 .

129. 330 U.S. 631 (1947).

130. Id. at 647 (Murphy, J., dissenting). 
principle of manifest criminality in setting minimum requirements for a finding of criminality.

Finally, let us return to the history of larceny and see whether the requirement of an act that is incriminating on its face helps us understand the relevant data. Rather than argue that the evidence supports the thesis, I will simply list the data.

1. In selecting a rationale for The Carrier's Case, all of the important common-law commentators fastened on the event that obviously incriminated the carrier: the breaking open of the bales. ${ }^{131}$ Blackstone explained the rule by stating that at that moment "the animus furandi is manifest." 132

2. In his opinion in The Carrier's Case, Nedeham used language that stresses the importance of clandestine behavior: "if ... I come secretly like a felon . . . and I take goods secretly like a felon ...."133

3. A color of title, namely, the appearance of a rightful claim, precluded commission of larceny. ${ }^{134}$

4. Receiving goods by delivery in the ordinary course of business could not, regardless of the actor's intent, constitute a felonious taking. ${ }^{135}$

5. Riding off with a horse already in one's possession could not constitute larceny. Taking sheets from a hotel, silverware from a restaurant, or a tie from a store, ${ }^{136}$ by contrast, were all

131. See note 14 supra.

132. $4 \mathrm{~W}$. BLACKSTONE, supra note 9 , at $* 230$.

133. 64 SELDEN Soc'y, supra note 2, at 33. Nedeham was the only adviser to the King who favored a finding of felony when the case was discussed in the Exchequer Chamber. Id. at 33. His opinion discusses two other cases of felonious taking: where the possession is terminated by delivery to the destination; and where one has custody but not possession. Both of those examples are compatible with the thesis that Nedeham perceived the clandestine manner of taking as important in classifying the conduct as felony. Professor Weinreb's argument to the contrary merely asserts, without evidence, that Nedeham must have meant something different. See Weinreb, supra note 4, at 299 . Nonetheless, I agree with Professor Weinreb that one should not put too much empahsis on this or on any other reported opinion of the discussion in the King's Council.

134. See p. 335 supra.

135. This model of a non-punishable taking influenced the court's reasoning in Topolew'ski v. State, 130 Wis. 244, 109 N.W. 1037 (1906) (defendant picked up meat barrels left for him as part of plan to catch him in act of stealing). The opinion is analyzed in RETHINKING at 72-76.

136. The last example comes from Chisser's Case, 83 Eng. Rep. 142 (K.B. 1678). According to the third paragraph of the opinion, the larceny occurred "when Chisser run away with the goods." Id. at 143 . Professor Weinreb concurs in this reading. Weinreb, supra note 4 , at 304 n.57. Yet, for reasons I do not understand, he does not wish to recognize an ambiguity in the opinion that in fact supports his original reading of the history of larceny. In Lord Raymond's report, the second paragraph of the opinion says that "the act subsequent, viz. his running away with them, explains his intent precedent." 83 Eng. Rep. at 142 
cases where the taker merely had custody and therefore could be guilty of larceny.

6. In arguing against conviction in The Queen v. Middleton, Bramwell stressed that the defendant's act "was different from a privy [clandestine] or forcible taking." 137

7. In Middleton and in later cases, only judges arguing against liability rely on the doctrines of delivery and trespass. ${ }^{138}$

It does not require a great leap of imagination to find that all of those phenomena are informed by the principle that the courts should punish only incriminating takings. The historical argument, as I developed it in my earlier work, ${ }^{139}$ traces the principle of manifest criminality to the private execution of the fur manifestus (manifest thief) in Roman law and analogous practices in Greek and Jewish law. The historical development, in brief, seems to have proceeded in three basic stages: first, the private execution of manifest thieves; second, the public punishment of manifest and only of manifest thieves; and third, the metamorphosis of larceny and the ascendency of the subjective theory of larceny.

There is considerable indirect evidence for the view that prior to the metamorphosis of larceny, our ancestors understood thieving as conduct with a particular outward manifestation. Why do we use the words "stealthful" and "furtive" as we do? Built into our notion of stealthful behavior is a sense of stealing as an act on the sly. ${ }^{140}$ An open taking "under a color of right" could not be larceny, re-

(emphasis in original). That language, and the example of larceny in fraudem legis cited in support of it, id., supports East's conclusion that larceny in The King v. Pear, in The Carrier's Case, and in Chisser's Case occurred at $T_{1}$, the time of receipt. Professor Weinreb's casebook supports East's theory of larceny. L. WEINREB, supra note 1, at 377. Now he apparently disavows the evidence that supports him, for he claims that "[s]uch a reading of [Chisser's Case] is not serious." Weinreb, supra note 4, at 304 n.57.

137. L.R. 2 Cr. Cas. Res. 38, 56 (1873).

138. See p. 345 infra. Professor Weinreb treats "trespass" as an unproblematic element in the definition of larceny. Yet his own efforts to define "trespassory taking" are inconsistent. At one point, he defines "physical trespass" simply as "an actual taking of property from the possession of another person." Weinreb, supra note 4, at 310-11. On this definition, one could hardly understand how the court in Topolewski v. State, 130 Wis. 244, 109 N.W. 1037 (1906), could conclude that the taking of the barrels did not amount to a "trespass"; for surely Topolewski "took the property from the possession of another." At another point, Professor Weinreb stresses the element of "taking from possession against the will of the possessor." Weinreb, supra note 4, at 306. Yet he never considers whether the quality of trespass adds something to the elements of taking from possession and taking against the will of the owner. Focusing on the additional quality of a "privy or forcible taking" might explain why, in the nineteenth century, only those opposed to liability relied on the term "trespass."

139. See RETHiNking at 76-81; Fletcher, supra note 32, at 476-81.

140. The word "stealth" has the same origin as "steal." 10 Oxford ENGlish DictionaRx 884,887 (1933). "Furtive" derives from fur, the Latin word for thief. $4 \mathrm{id}$. at 620 . 
gardless of the intent. Keeping something under one's control could not be larceny, regardless of the intent. Yet taking goods in a manner that was unusual and suspicious-sheets from a hotel, silverware from a restaurant, a tie from a store-that was larceny. ${ }^{141}$

In many modern cases, judges have used the word "trespass" to capture the moment of clandestine or forcible behavior in a larcenous taking. ${ }^{142}$ Thus, the dissent in Middleton spoke of trespass in objecting to the conviction of someone whose taking of excess cash from a bank teller was hardly incriminating. Similarly, the court in the case of State $v$. Topolewski invoked the idiom of trespass to express its intuition that excessively facilitating a taking deprived the act of precisely those qualities that could render it felonious. ${ }^{143}$

In this brief sketch of the theory, I shall not rehearse the broader social and philosophical implications of the fall of manifest criminality and rise of subjective criminality. ${ }^{144}$ These broader issues lie far beyond the range of the present debate in which I contend only that we cannot understand the history of larceny without elaborating conflicting conceptions of criminality. Historical understanding requires that we probe beyond Professor Weinreb's banal thesis that the law of larceny reflects "the interplay between legal doctrine and changing social perceptions." 145

\section{Objections to Manifest Criminality}

Interpretive theories never persuade everyone. Yet they rarely have the power to engender the kind of reaction we have witnessed in Professor Weinreb's article. Let me see if I can sort out his arguments against my theory. The basic move is to deny that there are any discontinuities in the history of larceny, and hence that there is any evidence in need of interpretation. The second move is to invoke a normative argument against my historical account. The normative claim is that a preoccupation with manifest criminality is dangerous, for it could lead to disregarding intent altogether. ${ }^{146}$

141. For a survey of those cases, see Rethinking at 61-66.

142. Ste, $\varepsilon$. . , The Queen v. Middleton, L.R. 2 Cr. Cas. Res. 38, 53 (1873) (Martin, B., dissenting); $i d$. at 57-58 (Bramwell, B., dissenting).

143. It is significant that in Topolewski v. State, 130 Wis. 244,109 N.W. 1037 (1906), the court's opinion never says directly that the facilitation of the taking amounted to a delivery. It hedges the argument by saying that the company's setting out of the barrels was a delivery "in practical effect." Id. at 256,109 N.W. at 1041. For a full analysis of the rhetoric in the opinion, particularly of the significance of using the terms "delivery," "consent," and "trespass," see Rethinking at 70-76, 86-88.

144. For fuller elaboration, see Rethinking at 100-02.

145. Weinreb, supra note 4 , at 309 .

146. Id. at 318. 
The third move is to attack the coherence of manifest criminality by stressing the difficulty of resolving borderline cases. That the standard is fuzzy at the fringes suggests perhaps that no rational person would take it seriously. In any event, we should no longer urge the principle in fields like attempts.

The first two objections need no longer detain us. ${ }^{147}$ The third move, however, raises some intriguing points. There is no doubt that one can find borderline cases of manifest larceny. But does it follow that there are no clear cases? If there are borderline cases of causation, negligence, malice, insanity, and duress, does it follow that those concepts have no core of undisputed application? In fact, of course, most of the important concepts in the law find clear application in some cases and disputed application in others. ${ }^{148}$

In seeking to understand the history of larceny, the important question to ask is not whether a particular person today can effectively apply the principle of manifest criminality to borderline cases. Rather, we should ask whether we can imagine others proceeding toward their decisions by responding implicitly to the principle. In order to establish that point, it seems to me, I need only demonstrate that some cases are relatively clearer instances of manifest criminality than others. If it is possible to rank cases by the degree to which conduct reveals the intent, then it is possible to begin discussing how manifestly criminal the behavior was required to be for different offenses at different stages of history. Let us consider, then, the following ordered pairs of acts:

1. It is more indicative of a treasonous purpose (A) to give an enemy agent a military map ${ }^{149}$ than (B) to meet with an enemy agent at a restaurant. ${ }^{150}$

2. It is more indicative of a murderous intent (A) to put an ineffective dose of poison in someone's coffee ${ }^{151}$ than (B) to put sugar in his coffee..$^{152}$

147. I have attempted to refute the first objection by restating the discontinuities in the history of larceny. See pp. 334-36 supra. The second objection rests on a misreading of my argument that confuses manifest criminality with strict liability. See pp. 337-38, 340 supra.

148. See H.L.A. Hart, The Concept of Law 121-37 (1961).

149. Justice Murphy gave this as an example of an overt act of giving aid and comfort to the enemy that would be "consistent only with a treasonable intention." Haupt v. United States, 330 U.S. 631, 647 (1947) (Murphy, J., dissenting).

150. See Cramer v. United States, 325 U.S. 1 (1945) (conviction reversed because government failed to allege and prove overt act of giving aid and comfort to enemy).

151. See, e.g., Commonwealth v. Kennedy, 170 Mass. 18, 48 N.E. 770 (1897); State v. Glover, 27 S.C. 602, 4 S.E. 564 (1888).

152. See State v. Cilarissa, 11 Ala. 57 (1847) (conviction for attempted murder reversed because indictment did not allege that putative poison was toxic); The Queen v. Osborn, 


\section{Reply to Weinreb}

3. It is more indicative of an intent to commit a felony inside a house (A) to enter at night through the chimney $y^{153}$ than (B) to enter during the day through the front door. ${ }^{154}$

4. It is more indicative of animus furandi for someone in possession of another's package (A) to open the package and remove the contents ${ }^{155}$ than (B) to keep the package substantially longer than he should. ${ }^{156}$

5. It is more indicative of animus furandi (A) for a passenger to leave an airplane with silverware provided at dinner ${ }^{157}$ than (B) for a mechanic impermissibly to use a car given to him for repair. ${ }^{158}$

6. It is more indicative of animus furandi (A) for a suspected thief to enter a house, open a desk drawer, and remove the contents $^{159}$ than (B) for a suspected thief to remove barrels of meat left for him on the loading dock of a packing company. ${ }^{160}$

All that the theory of manifest criminality requires is that we are able to order those cases in that way. If we can do so, then we can consider the possibility that, upon finding the requisite intent proven beyond a reasonable doubt, some judges and commentators would favor liability for the first, more incriminating acts in each of those six pairs, but reject liability for the second, less incriminating

84 J.P. 63 (1920) (prescribing innocuous substance as abortifacient would not support liability for attempt to procure abortion).

153. Entering through the chimney constituted "breaking" in common-law burglary. 4 W. Blackstone, supra note 9 , at $* 226 ; 1 \mathrm{M}$. HALE, supra note 9 , at 552.

154. This hypothetical situation is a composite of two elements: a daytime entry, which is presumably less likely to be threatening than the nighttime entry required at common law, see 4 W. Blackstone, supra note 9 , at $* 224$, and an entry through the front door, which would not have been a "breaking" at common law, see id. at $\$ 226$.

155. This, of course, was the situation in The Carrier's Case. See pp. 320-21 supra.

156. See p. 320 supra (describing hypothetical Clever Carrier's Case). In an effort to make the behavior of the clever carrier appear criminal, Professor Weinreb suggestively says of the clever carrier that he "sells the bales intact to a stranger, pockets the proceeds, and departs." Weinreb, supra note 4, at 303. Note the additional act of "pocketing the proceeds," which obviously connotes surreptitious behavior. The clever carrier's conduct is less incriminating; for compared with breaking open the bales, the act of selling the goods at market is much more likely to be the authorized act of a servant.

157. Nedeham's opinion in The Carrier's Case gives a similar example as an illustration of felonious taking. 64 SELDEN Soc'y, supra note 2 , at 33 .

158. The mechanic would enjoy immunity from the liability for larceny, because, as Coke said, "he hath the possession of it once lawfully." E. CokE, supra note 9, at 107. For a discussion of this principle of immunity, see RETHINkING at 81-83.

159. Ste The King v. Egginton, 168 Eng. Rep. 555 (1801) (conviction upheld despite effort by owner to set trap for thieves).

160. Topolewski v. State, 130 Wis. 244,109 N.W. 1037 (1906) (conviction reversed on ground that effort to set trap went too far and deprived taking of quality of trespass). 
acts. Entertaining that possibility might make one receptive to the thesis that particular doctrinal disputes respond to conceptually deeper concerns about the manifestly criminal nature of the allegedly criminal act.

Explicating the internal tensions in our present and past law requires some normative flexibility. I would never have come upon the principle of manifest criminality unless the values that it represents had some claim on me. Indeed, there is much to be said for those values. ${ }^{161}$ Yet the metamorphosis of larceny would never have occurred unless there were persuasive considerations favoring the principles of subjective criminality. Not surprisingly, there are strong arguments for and against each conception of criminality. ${ }^{162}$ Though I tend to side with the principles of manifest criminality, a preference for one side is not as important as recognizing the existence of basic ideological conflict in the legal system.

161. See Rethinking at 88-90. For a more elaborate defense of the values implicit in the pattern of manifest criminality, see Fletcher, Legality as Privacy, in LiBERTY AND THE Rule of Law 482 (R. Cunningham ed. 1979).

162. For a strong argument against restricting the law of treason to manifestly criminal conduct, see Cramer v. United States, 325 U.S. 1, 32 (1945) ("Treason-insidious and dangerous treason-is the work of the shrewd and crafty more often than of the simple and impulsive.") The same argument applies to the law of larceny and attempt. For a review of other arguments bearing on the conflict between subjective and manifest criminality, particularly in the law of attempts, see Rethinking at 139-84. 


\title{
The Yale Law Journal
}

Volume 90, Number 2, December 1980

\author{
John M. Campbell \\ Editor-in-Chief
}

\author{
Michael D. Klausner \\ Note is Topics Editor \\ Vincent J. Chiarello \\ Perry Dane \\ Stuart A.C. Drake \\ John D. Echeverria \\ Note Editors
}

David E. Van Zandt

Managing Editor

Carol F. Lee

Dwight C. Smith III

Richard G. Taranto

Kenneth S. Taymor

Donald J. Toumey

Article \& Book Review Editors
H. Craig Becker

Donald S. Collat

Peter M. Daub

F. Tayton Dencer Janet L. Dolgin

William V. Dunlap

Frances $H$. Foster

Charles W. Fournier
Hugh H. Jacobson

Steven M. Kamp

David B. Keto

Judith A. Lachman

Deborah Leavy

R. Gustave Lehouck II

Robert L. McGlasson
Suzanne E. Meeker

Rachel F. Moran

Russell G. Pearce

Patrick W. Shea

Steven A. Steinbach

Jeffrey W. Stempel

E. Michael Paul Thomas

Anne E. Verdon

Assisiants to the Editors Mary Ann McClure, Pamela Willmott

\section{Student Contributors to This Issue}

Perry Dane, Religious Exemptions Under the Free Exercise Clause: A Model of Competing Authorities

Robert L. McGlasson, Tipping the Scales of Justice: A Race-Conscious Remedy for Neighborhood Transition

Steven A. Steinbach, A Procedural Framework for the Disclosure of Business Records Under the Freedom of Information Act 